Mukherjee, I., and Large, R.R., 2020, Co-evolution of trace elements and life in Precambrian oceans: The pyrite edition: Geology, v. 48, https://doi.org/10.1130/G47890.1

\title{
Co-evolution of trace elements and life in Precambrian oceans: The pyrite edition
}

\section{AVAILABILITY AND BIOAVAILABILITY}

The concentration of trace elements (TEs) in the ocean through time, has been controlled by a combination of factors, such as redox state of the atmosphere and ocean, erosion rates and source rock composition. Physical and chemical disintegration of rocks and subsequent release of TEs are strongly affected by redox buffers, like $p \mathrm{O}_{2}$, as TEs are redox sensitive (undergo change in valence state) or sensitive to oxidative weathering (Saito et al., 2003; Zerkle et al., 2005; Scott et al., 2008, Smith and Huyck, 1998). While weathering results in efficient breakdown of materials, mobility of TEs is controlled by erosion processes, which relies on regional active tectonics. Another crucial factor is the composition of the upper most continental crust (UMCC) that dictate the chemical nature of the TE flux. Surface continental rocks are the primary source of the nutrient flux to the oceans, and different rock compositions (e.g., felsic or mafic) have differing concentrations and types of TEs (nutrient vs non-nutrient) available for weathering and erosion (Taylor and McLennan, 1985; Large et al., 2018). Hydrothermal input of TEs into the ocean also add to the overall budget, albeit in much lower proportions compared to terrestrial input (Stueken et al., 2015; Bruland, 2014; Jeandel and Oelkers, 2015).

Linking first-order availability with uptake or bioavailability is not straightforward and demands additional explanation. Availability or co-availability of elements do not necessarily imply utilisation by organisms - as it depends on other parameters such $\mathrm{pH}$, redox potential, salinity, volume of water, water column pressure, radiation, temperature and total organic content. However, the most important (and rather indispensable) factor facilitating bioavailability is the total concentration of the element and its chemical speciation - which by extension, makes availability of an element, the most important prerequisite. Its only when an 
element is made available, that the various water column properties become crucial for utilisation of elements by organisms. Below, are a few examples explaining those properties.

Hydrogen ion activity or $\mathrm{pH}$ affects metal speciation, solubility from mineral surfaces and transport of elements (John and Levanthal, 1995). Similarly, salinity (increase or decrease) could potentially increase and decrease ionic compositions (Merino et al., 2015). Interestingly, for organisms, responding to changing environmental/water column conditions such as $\mathrm{pH}$ and salinity, aid in developing strategies. For instance, undesirable $\mathrm{pH}$ and salinity fluctuations can be metabolically regulated by organisms via production of organic metabolites (lactic acid, acetic acid) and organic solutes respectively (Merino et al., 2015). Organisms may also undergo changes in cell organelle morphologies in order to maintain metal content within the cell. For instance, occurrence of specific protein folds to alter their binding preferences to certain elements (Gladyshev and Zhang, 2011). Cells may undergo production of unsaturated fatty acids to enhance cell fluidity in case of increased water pressure. Temperature also affects rates of chemical reactions - but it impacts both chemical and biological rates equally, hence net bioaccumulation may remain the same (Luoma, 1983). The residence time of trace elements (time the TE are present in the ocean as dissolved or bio-active species, before they sink into the seafloor sediments attached to organic matter or other minerals; Balistrieri et al., 1981) also affects its availability and bio-availability. Today, conservative trace elements (Mo) have longer residence time $\sim 100,000$ years and have a high concentration in the current ocean; nutrient like elements $(\mathrm{Zn}, \mathrm{Cd}, \mathrm{Cr}, \mathrm{V}, \mathrm{Se}, \mathrm{Ni}, \mathrm{Cu})$ have an intermediate residence time of 500 to 100,000 years, and scavenged elements (e.g. Co, Mn, Fe) have short residence time of $<500$ years and relatively low concentration in the current ocean (Nozaki, 2001). However, all these TE are also redox sensitive (or sensitive to oxidative weathering) and therefore their solubility and residence times in past oceans will undeniably differ compared to the modern ocean, due to temporal changes in oxygen in the 
ocean-atmosphere system. One of the objectives of this study is to provide some insights into such TE attributes in past oceans as discussed below.

It is key to highlight the importance of availability of an element over extended periods of time (first order - in millions of years timescale) on bioavailability. Its only when this requirement is fulfilled that other water column variables modify an element's bioavailability. Also, organisms are capable of strategically adapting to changing $\mathrm{pH}$, salinity etc. to tap or detox elements - if and only if, they are available.

\section{Scavenged, nutrient and conservative elements in the early Earth}

Without adequate information (rate of supply of elements into the ocean, nature of removal sinks, mixing patterns, depth profiles of elements), it is almost impossible to devise a list of elements outlining their scavenged, nutrient or conservative characteristics through geological time as we know today. However, it is possible to comment on their most likely behaviour. Molybdenum, for instance, certainly did not behave conservatively in a reduced atmosphere-ocean scenario. This leaves us with option of Mo being either scavenged or nutrient. Knowing the extensive utilisation patterns of Mo in prokaryotes, it must have exhibited nutrient-like character rather than scavenged. The latter would render the element unavailable altogether and if that was the case, we should have seen that reflected in the genomic sequences of the prokaryotic species. The element Co, that displays scavenged characteristics today, may have either been a nutrient or conservative element in the Archean. That is because $\sim$ Fe-Mn oxides and hydrooxides, that efficiently scavenge Co today, were absent. Without knowing the input rate and amount of $\mathrm{Co}$ in the ocean of any given time, it is rather impossible to comment on whether it was nutrient or conservative definitively. 
ADDITIIONAL METHOD

\section{Analytical specifications and data reduction techniques}

The LA-ICP-MS analyses of trace elements in pyrite and the black shale matrix were carried out using a New Wave Research UP-193ss laser microprobe coupled to an Agilent 7700s quadrupole ICP-MS for the following elements and their respective isotopes, ${ }^{13} \mathrm{C},{ }^{23} \mathrm{Na},{ }^{24} \mathrm{Mg},{ }^{27} \mathrm{Al},{ }^{29} \mathrm{Si},{ }^{34} \mathrm{~S},{ }^{39} \mathrm{~K}$, ${ }^{43} \mathrm{Ca},{ }^{49} \mathrm{Ti},{ }^{51} \mathrm{~V},{ }^{53} \mathrm{Cr},{ }^{55} \mathrm{Mn},{ }^{57} \mathrm{Fe},{ }^{59} \mathrm{Co},{ }^{60} \mathrm{Ni},{ }^{65} \mathrm{Cu},{ }^{66} \mathrm{Zn},{ }^{75} \mathrm{As},{ }^{77} \mathrm{Se},{ }^{85} \mathrm{Rb},{ }^{88} \mathrm{Sr},{ }^{90} \mathrm{Zr},{ }^{95} \mathrm{Mo},{ }^{107} \mathrm{Ag},{ }^{111} \mathrm{Cd}$, ${ }^{118} \mathrm{Sn},{ }^{121} \mathrm{Sb},{ }^{125} \mathrm{Te},{ }^{137} \mathrm{Ba},{ }^{157} \mathrm{Gd},{ }^{178} \mathrm{Hf},{ }^{181} \mathrm{Ta},{ }^{182} \mathrm{~W},{ }^{195} \mathrm{Pt},{ }^{197} \mathrm{Au},{ }^{202} \mathrm{Hg},{ }^{205} \mathrm{Tl},{ }^{206} \mathrm{~Pb},{ }^{207} \mathrm{~Pb},{ }^{208} \mathrm{~Pb},{ }^{209} \mathrm{Bi}$,

${ }^{232} \mathrm{Th}$ and ${ }^{238} \mathrm{U}$. For pyrite trace element analyses, three primary reference materials used to quantify the abundances of chalcophile elements, lithophile elements, and sulphur abundances, respectively. They are STGL2b2 (in-house reference material for calibration of relative element sensitivities; Danyushevsky et al., 2011) for chalcophile elements, GSD-1G (USGS reference glass; Jochum et al., 2005) for silicates and a stoichiometric pyrite PPP-1 crystal (Gilbert et al., 2014) for sulphur. The three standards or reference material were analysed twice, before and thereafter, 15 to 20 analyses ( every 1.5 hours) as well as at the beginning and end of a run. Backgrounds were analysed for 30seconds before the signal from the ablated sample was acquired for $40-60$ seconds $\left(\sim 3.5 \mathrm{~J} / \mathrm{cm}^{2}\right.$ laser fluence and $5 \mathrm{~Hz}$ laser repetition rate). Ablation took place in a $\mathrm{He}$ atmosphere, flowing at a rate of $0.8 \mathrm{l} / \mathrm{min}$, along with mixing of the ablation stream with the Ar carrier gas $(0.851 / \mathrm{min})$. For black shale matrix analyses, glass standards were analysed with $51 \mu \mathrm{m}$ spot size in order to alleviate heterogeneity of the standards for key elements such as Au and Tl. Refer Large et al., 2018 for detailed method. Please refer Mukherjee et al., 2018 and Stepanov et al., 2020 for additional details on the LA-ICP-MS technique such as dwell time, sweep time etc.

\section{Data reduction}

Data reduction techniques for pyrite and trace element analyses have been published in Large et al., 2014, 2015, 2018, 2019, Mukherjee et al., (2018), Stepanov et al., 2020. Both matrix and pyrite analyses were used in the data reduction process in order to account for mixing of pyrite and matrix components during LA-ICP-MS analyses of small pyrite grains. Data reduction techniques included an algorithm based on subtraction of the matrix component estimated from mass balance (Large et al. 
2014). The method had a few disadvantages owing to subjectivity in selection of the pyrite and matrix compositions and difficulty in determining uncertainties. The data processing technique was modified where analyses of pyrite were processed by an Excel based data reduction software developed inhouse, which uses a linear regression-based algorithm for determining chalcophile and siderophile abundances relative to sulphur, for calculation of sulfide composition. The method has been elaborately discussed in Stepanov et al., 2020.

\section{Sample descriptions and locations}

For the latest sample descriptions and locations, refer to table DR1 and Large et al., 2019 and Steadman et al., 2000 for a more detailed description of sample locations.

\section{Additional figures}

Time series graphs of selected key trace elements in pyrite are presented in Fig. DR2 and a more complete set of figures of all $17 \mathrm{TE}$ can be found in Large et al. (2018). Trace elements not concentrated in pyrite, but rather the organic-bearing clay matrix including non-sulfide $\mathrm{Fe}, \mathrm{Cr}, \mathrm{V} \mathrm{P}$ are presented in Fig. DR3. These graphs demonstrate that there is significant variation in all trace elements in pyrite and organic matrix, and consequently the global ocean, through geological time.

\section{REFERENCES}

Large, R.R., Halpin, J.A., Lounjeva, E., Danyushevsky, L.D., Maslennikov, V.V., Gregory, D., Sack, P.J., Haines, P., Long, J.A., Makoundi, C., Stepanov, A.S., 2015, Cycles of nutrient trace elements in the Phanerozoic ocean: Gondwana Research, v. 28, p.1282-1293

Large, R.R., Mukherjee, I., Zhukova, I., Corkrey, R., Stepanov, A., and Danyushevsky, L.V., 2018, Role of upper crustal composition in the evolution of the Precambrian oceanatmosphere system: Earth Planetary Science Letters, v. 487, p. 44-53.

Large, R., Mukherjee, I., Gregory, D., Steadman, J., Corkrey, R., and Danyushevsky, D., 2019, Atmosphere oxygen cycling through the Proterozoic and Phanerozoic: Mineralium Deposita, v. 54(4), p. 485-506 (DOI: 10.1007/s00126-019-00866-8), MIDE-D-1800154.3

Large, R.R., Halpin, J.A., Danyushevsky, L.V., Maslennikov, V.V., Bull, S.W., Long, J.A., Gregory, D.D., Lounejeva, E., Lyons, T.W., Sack, P.J., McGoldrick, P.J., Calver, 
C.R., 2014, Trace element content of sedimentary pyrite as a new proxy for deep-time ocean-atmosphere evolution: Earth Planetary Science Letters, v. 389, p. 209-220.

Mukherjee, I., Large, R.R., Corkrey, R., Danyushevsky, L., 2018, The boring billion, a slingshot to complex life on earth: Nature Science Reports, v. 8, p. 4432.

Zhang, Y., and Gladyshev, V., 2011, Comparative genomics of trace element dependence in biology: Journal of Biological Chemistry, v. 286(27), p. 23623-23629

Saito, M.A., Goepfert, T.J., Noble, A.E., Bertrand, E.M., Sedwick, P.N., DiTullio, G.R., 2010, A seasonal study of dissolved cobalt in the Ross Sea, Antarctica: micronutrient behavior, absence of scavenging, and relationships with $\mathrm{Zn}, \mathrm{Cd}$, and P: Biogeosciences, $\mathrm{v}$. 7(12), p. 4059-4082

Balistrieri, L., Brewer, P.G. and Murray, J.W., 1981, Scavenging residence times of trace metals and surface chemistry of sinking particles in the deep ocean: Deep Sea Research Part A. Oceanographic Research Papers, v. 28(2), p.101-121.

Nozaki, Y., 2010, Elemental Distribution: Overview, In: Steele, J., Thorpe, S.A., Turekian, K.K. (Eds.), Marine Chemistry and Geochemistry: A Derivative of Encyclopedia of Ocean Sciences, 2nd Edition. Elsevier/Academic Press, Amsterdam, p. 7-12.

Zerkle, A. L., House, C. H. \& Brantley, S. L., 2005, Biogeochemical signatures through time as inferred from whole microbial genomes. American Journal of Science, v. 305, p. 467-502.

Taylor, S. R. and McLennan, S. M., 1985, The Continental Crust: Its Composition and Evolution. Blackwell (Oxford), 312pp.

Merino N, Aronson H et al. (2019) Living at the Extremes: Extremophiles and the Limits of Life in a Planetary Context. Frontiers in microbiology. 10780

Scott, C., Lyons, T.W., Bekker, A., Shen, Y., Poulton, S.W., Chu, X., and Anbar, A.D. (2008) Tracing the stepwise oxygenation of the Proterozoic ocean. Nature, 452, 456-459.

Longerich, H.P., Jackson, S.E., and Günther, D. (1996) Laser ablation inductively coupled plasma mass spectrometric transient signal data acquisition and analyte concentration calculation. Journal of Analytical Atomic Spectrometry, 11, 899-904.

Smith, K.S., and Huyck, H.L.O. (1999) An overview of the abundance, relative mobility, bioavailability, and human toxicity of metals, in Plumlee, G.S., and Logsdon, M.J., eds., The environmental geochemistry of mineral deposits, Part A: Processes, techniques, and health issues, Reviews in Economic Geology, vol. 6A, Chapter 2: Littleton, p. 29-70, Society of Economic Geologists, Inc., Colorado

Danyushevsky, L., Robinson, P., Gilbert, S., Norman, M., Large, R., McGoldrick, P., and Shelley, M. (2011) Routine quantitative multi-element analysis of sulphide minerals by laser ablation ICP-MS: Standard development and consideration of matrix effects. Geochemistry: Exploration, Environment, Analysis, 11, 51-60

Jochum, K.P., Pfänder, J., Woodhead, J.D., Willbold, M., Stoll, B., Herwig, K., Amini, 
M., Abouchami, W., and Hofmann, A.W. (2005) MPI DING glasses: New geological reference materials for in situ $\mathrm{Pb}$ isotope analysis. Geochemistry Geophysics Geosystems, $6,1525-2027$.

Gilbert, S., Danyushevsky, L., Goemann, K., and Death, D. (2014) Fractionation of sulphur relative to iron during laser ablation-ICP-MS analyses of sulphide minerals: implications for quantification. Journal of Analytical Atomic Spectrometry, 29, 1024 1033.

Bruland, K., Middag, R., and Lohan, M.C., 2014, Controls of Trace Metals in Seawater: Treatise on Geochemistry, v. 8, p. 19 51, doi:10.1016/b978-0-08-095975-7.00602-1

Jeandel C, Oelkers E. 2015The influence of terrigeneous particulate material dissolution on ocean chemistry and global element cycles. Chem. Geol. 395, 50-6

John, D. A., \& Leventhal, J. S. (1995). Bioavailability of metals. Preliminary compilation of descriptive geoenvironmental mineral deposit models. In E. du Bray (Ed.) pp. 10-18. USGS, Denver.

Luoma, S.N., 1983, Bioavailability of trace metals to aquatic organisms - a review: Science of the Total Environment., v. 28, p. 1-22,

Stüeken E.E., Buick R., Anbar A.D., 2015, Selenium isotopes support free $\mathrm{O}_{2}$ in the latest Archean: Geology, v. 43 (3), p. 259-262

Stepanov, A., Danyushevsky, L., Large, R., Mukherjee, I., and Zhukova, I., 2020, deconvolution of the composition of fine-grained pyrite in sedimentary matrix by regression of time-resolved LA-ICP-MS data", American Mineralogist, DOI: 10.2138/am-2020-7202 

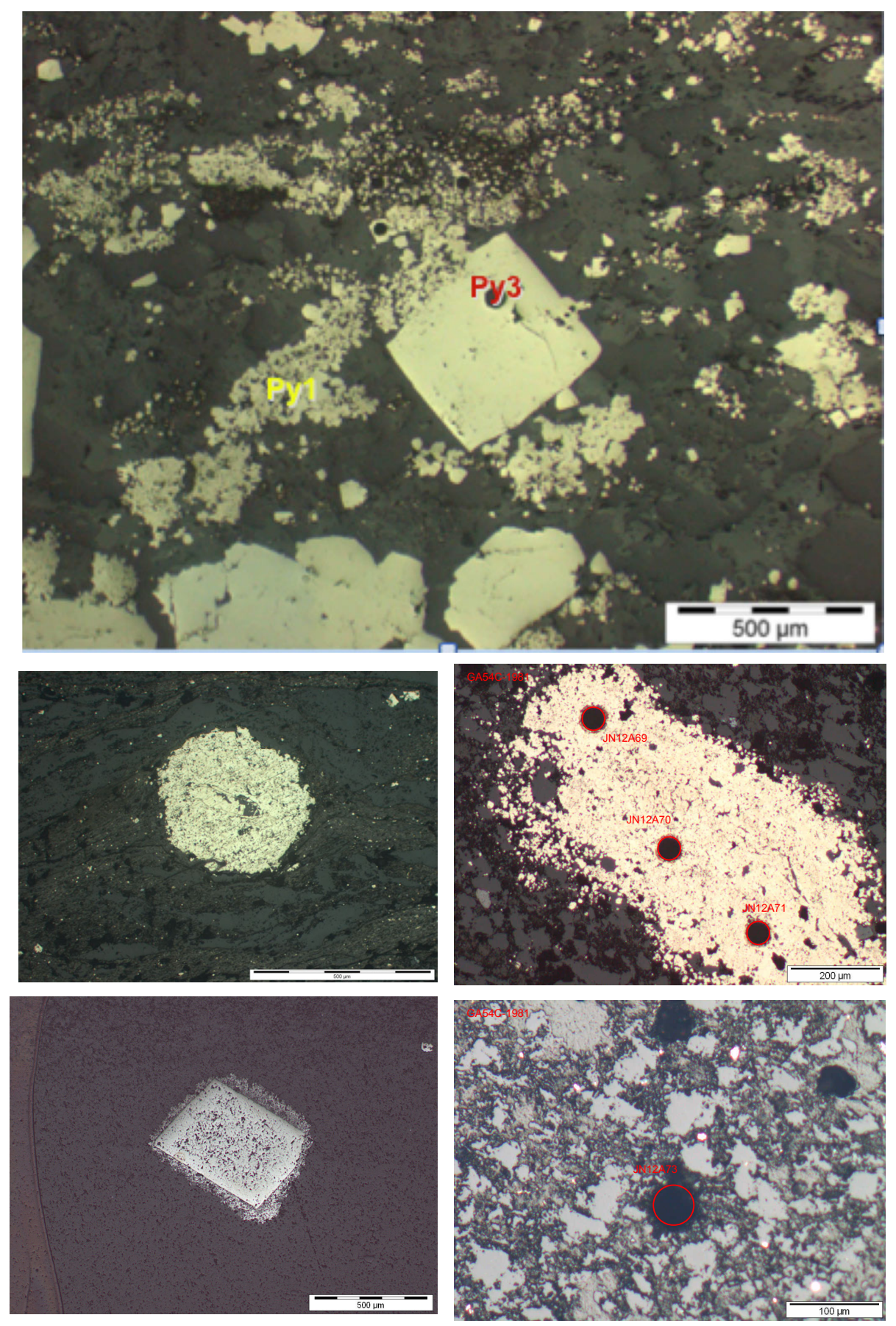

Figure S1: Various textures of pyrite under reflected light microscope. a) Fine grained anhedral marine pyrite (py1) and coarse euhedral pyrite (py3) of metamorphic origin. b) nodule of fine grained early diagenetic pyrite, c) aggregate of 3 coallesced nodules of early diagenetic pyrite. The black circles are lase burns 40 microns across. d) Euhedral metamorphic pyrite with fringe of fine marcasite. e) Laser burn in clay-rich matrix of a carbonaceous siltstone. The euhedral pyrite types were not analysed in this study. 

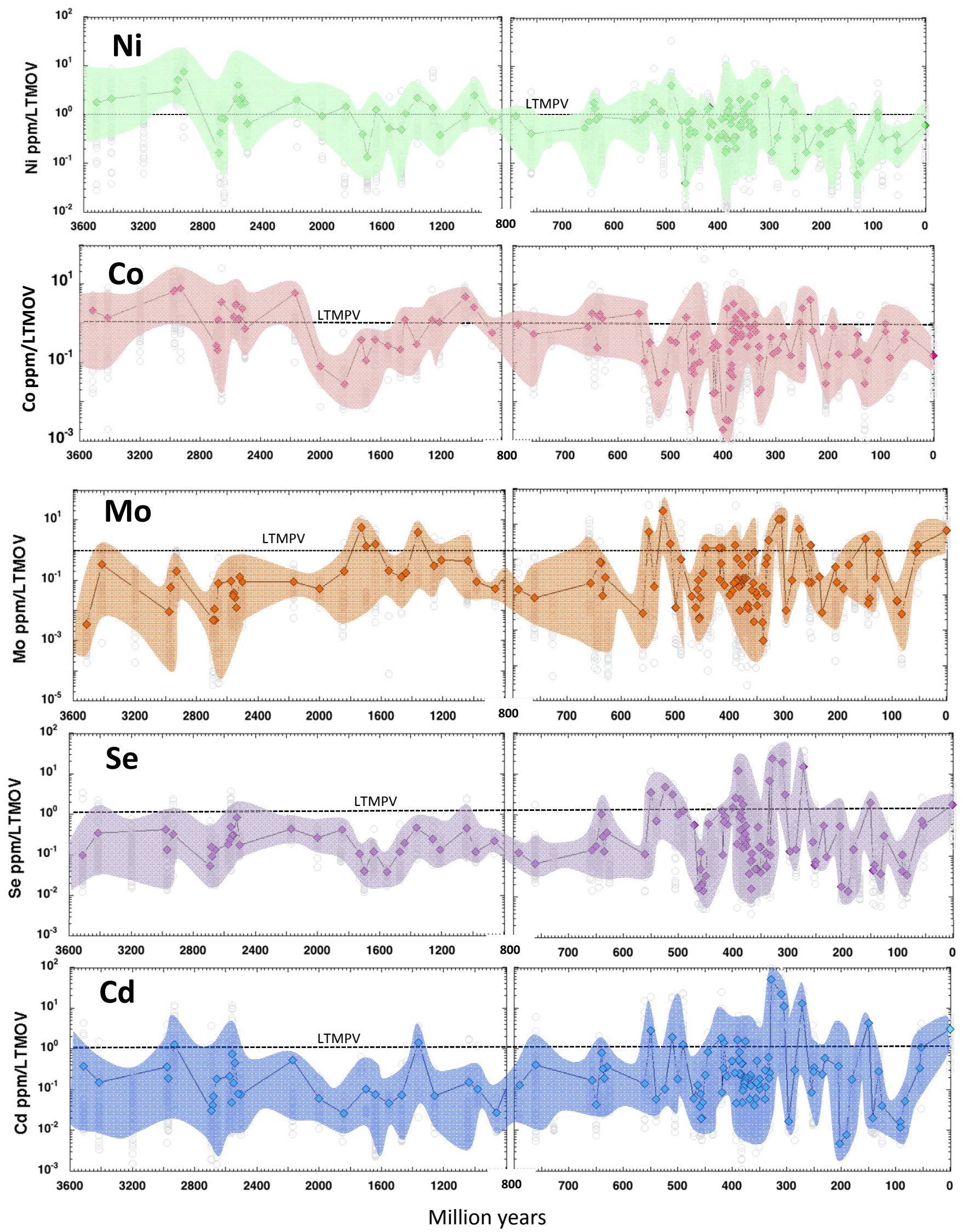

Fig. S2: Marine pyrite time series for $\mathrm{Ni}, \mathrm{Co}, \mathrm{Mo}$, Se and $\mathrm{Cd}$. The $\mathrm{y}$-axis is the concentration in marine pyrite in ppm divided by the LTMPV for the relevant trace element. Note the scale change at 800 Ma. Data from Large et al.(2018). 

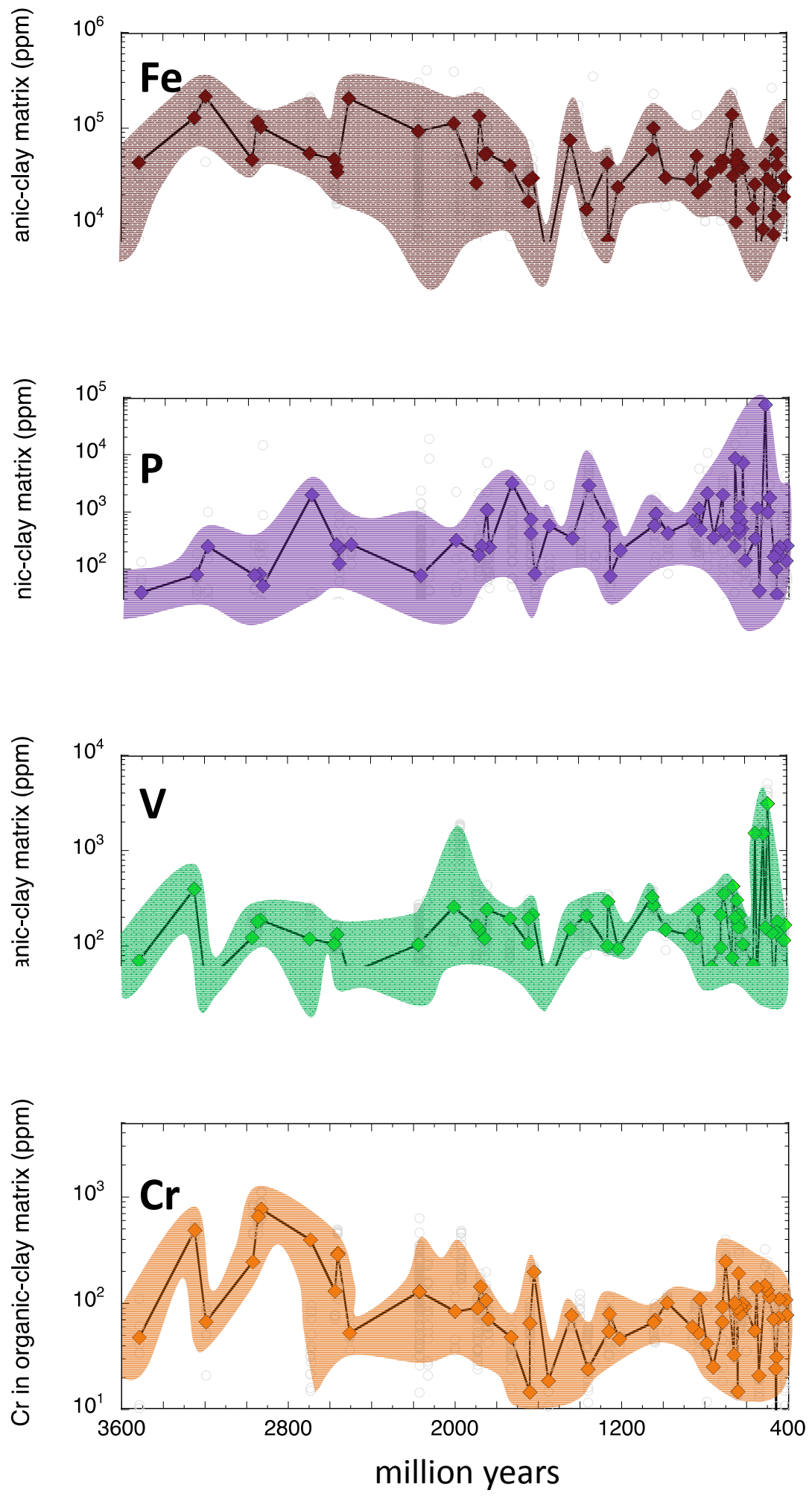

Fig. S3: Time series for Fe, P, V, Cr measured by LA-ICPMS in the organic matter-clay matrix of black shales.

Fig. DR3 